\title{
Hidden Victims
}


Critical Issues in Crime and Society

Edited by Raymond J. Michalowski Jr.

Critical Issues in Crime and Society

Rayond J. Michalowski Jr., Series Editor

Critical Issues in Crime and Society is oriented toward critical analysis of contemporary problems in crime and justice. The series is open to a broad range of topics including specific types of crime, wrongful behavior by economically or politically powerful actors, controversies over justice system practices, and issues related to the intersection of identity, crime, and justice. It is committed to offering thoughtful works that will be accessible to scholars and professional criminologists, general readers, and students. 


\title{
Hidden Victims
}

\section{The Effects of the Death Penalty on Families of THE ACCUSED}

\author{
SuSAN F. Sharp
}




\section{Library of Congress Cataloging-In-Publication Data}

Sharp, Susan F., 1951-

Hidden victims : the effects of the death penalty on families of the accused / Susan F. Sharp

p. $\quad \mathrm{cm}$. - (Critical issues in crime and society)

Includes bibliographical references and index.

ISBN 0-8135-3583-2 (hardcover : alk. paper) - ISBN 0-8135-3584-0 (pbk. : alk. paper)

1. Capital punishment-United States. 2. Death row inmates-United States-Family relationships. 3. Prisoners' families-United States.

I. Title. II. Series.

HV8699.U5S45 2005

362.82'9-dc22 2004020835

A British Cataloging-in-Publication record for this book is available from the British Library

Copyright (C) 2005 by Susan F. Sharp

Foreword Copyright (C) 2005 by Michael L. Radelet

\section{All rights reserved}

No part of this book may be reproduced or utilized in any form or by any means, electronic or mechanical, or by any information storage and retrieval system, without written permission from the publisher. Please contact Rutgers University Press, 100 Joyce Kilmer Avenue, Piscataway, NJ 08854-8099. The only exception to this prohibition is "fair use" as defined by U.S. copyright law.

Manufactured in the United States of America 